\title{
Mechanically Induced Reactivity of Solids $\dagger$
}

\author{
Ursula Steinike \\ Centre of Heterogeneauis Catalysis of KAI e.V.* \\ Hans-Peter Hennig \\ WITEGA-Research GmbH
}

\begin{abstract}
The action of mechanical energy on solids effects changes to their structure. The resulting structural defects lead to a storage of energy in the solid, which may raise its chemical reactivity. Investigations on the mechanically induced reactivity of solids have been carried out with the specific aim of influencing reaction processes in order to obtain high yields, high reaction velocities or selective reactions. On the basis of detailed structural investigations on mechanically treated quartz and hydrargillite, the interaction of the stressed solid with the surroundings has been explored (titanite formation, zeolite formation, polymorphous transformation, gas adsorption, $\mathrm{Na} \mathrm{a}^{+}$-elimination and hydration of amorphous $\mathrm{Al}_{2} \mathrm{O}_{3}$ ).

The investigations reveal that the size reduction which occurs during mechanical activation is not the decisive reason for reactivity enhancements, but that these are caused primarily by structural changes. Apart from the structural properties of solids, however, their chemical properties as well as those of the surroundings have an influence on their reactivity.
\end{abstract}

\section{Introduction}

People have known since ancient times that chemical reactions can be induced by mechanical energy, e.g. by friction or impact. Thus in prehistoric times, people generated light with the aid of flint stones. Also known are the effects of pressure and shear during geological epochs in the genesis of minerals, e.g. the formation of mica from feldspar by geotectonic movements. In 1911, Ostwald ${ }^{11}$ first used the term mechano-chemistry to describe the "influence" of mechanical energy on chemical reactions. The term "tribo-chemistry", which is often regarded as a synonym, is, however, restricted to chemical and physico-chemical changes of solids under the influence of mechanical energy ${ }^{2)}$.

In the $1920 \mathrm{~s}$, Tamman ${ }^{3)}$ studied the influence of mechanical treatment on the reactivity of solids. In the 1930 s it was primarily Fink ${ }^{4,5)}$ and later Bowden and Tabor $^{6}$, who investigated the effects of friction and abrasion on the oxidation reactions of metals and on their decomposition. They formulated the conception of "hot spots".

* Rudower Chaussee 5, 0-1199 Berlin, GERMANY

$\dagger$ Recieved Feb. 19, 1992
Up to the 1960 s, progress was based on empiricism. Only in the 1970 s were scientific investigations on the mechanism of the transfer of mechanical energy on solids begun ${ }^{7-11)}$. The range of mechanically treated solid substances is very wide, comprises both inorganic and organic materials, and extends from oxides to phosphates and silicates, from metals to ores and raw materials, and is often used as a process step in the synthesis of compounds having great practical relevance ${ }^{12-25)}$. Among organic substances, it is above all the polymers which aroused the interest of tribochemistry. But also, for example, the mechanical treatment of chloramphenicol-palmitate for the production of a physiologically active component is of importance ${ }^{26)}$.

The influence of mechanical energy on solids induces a multitude of elementary physicochemical micro and macroprocesses, which lead to a change of the structure, i.e. to the occurrence of structural defects such as changes of the surface, lattice distortions, conversion of long-range order distortions into short-range order and electronic defects. The processes taking place under the influence of mechanical energy are very complex, and depend on the kind and intensity of the mechanical stresses 
and the specific properties of the solids based on their lattice structure and, of course, their chemical nature. The mechanical energy may be transferred, e.g. by the impact of solid particles or by the induction of tensile and compressive forces in the powder mass (Fig. 1).

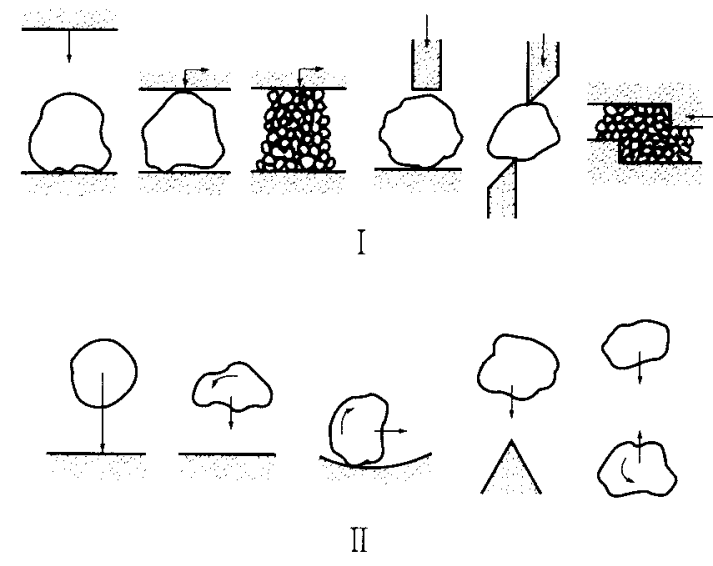

Fig. 1 Different stress mechanisms used in mechanically activating solid particles (2).

I stress between two surfaces (pressure and shearing stress)

II stressing by impact

Generally it has been established that with pressure and shear stresses, structural changes are concentrated at regions near the surface and diminish with increasing distance from the surface. With impact stresses, the size of the primary crystallite becomes smaller in the whole volume and the disturbance starts at the corners and borders ${ }^{8,9)}$.

Mechanical treatment leads to a storage of energy. According to theoretical investigations by Sigrist and Fichtner ${ }^{27)}$, it follows that apart from surface and inhomogeneous lattice distortions, homogeneous distortions may also contribute to this energy storage.

They applied their theory to experimental data from $\mathrm{MgO}$ and found maximum values of $30 \mathrm{~J} \mathrm{~g}^{-1}$ for inhomogeneous distortions, of $122 \mathrm{~J}$ $\mathrm{g}^{-1}$ for homogeneous and inhomogeneous distortions, and of $153 \mathrm{~J} \mathrm{~g}^{-1}$ for surface energy.

The reactivity of solids may often be considerably enhanced by mechanical treatment. Even such reactions as the formation of $\mathrm{Au}_{2} \mathrm{O}_{3}$ and $\mathrm{C}$ from $\mathrm{Au}$ and $\mathrm{CO}_{2}$, the formation of $\mathrm{CuO}$ or $\mathrm{Cu}_{2} \mathrm{O}$ and $\mathrm{C}$ from $\mathrm{Cu}$ and $\mathrm{CO}_{2}$, which cannot be accomplished thermally as a result of extremely negative affinity, proceed under mechanical treatment with a measurable velocity ${ }^{28}$.
Investigations on the mechanically changed reactivity of solids are being carried out with the aim of deliberately influencing the reaction processes of the solids concerned. For example, in chemical syntheses, the highest possible yield, and a high velocity and selectivity are aimed at. A specific influence on the reaction processes requires a knowledge of the relation between the real structure and kinetic parameters.

By means of some examples, the influence of the mechanical treatment on the structure and reactivity of solids will be demonstrated and some conclusions of general application are given.

\section{Examples of Mechanical Activation}

\subsection{Reactivity of Mechanically-Treated Quartz}

The effect of mechanical energy on the structure of quartz has been described in detail by Steinike et al. ${ }^{8}$. Mechanical activation leads to changes in the long and short-range order caused by lattice distortions and broken bonds. The mechanically-treated quartz is in a partially crystalline state. It still contains typical elements of the crystalline quartz structure and is characterized by the absence of long-range order (Fig. 2).

\subsubsection{Formation of Titanite}

Titanite $\left(\mathrm{CaTiSiO}_{5}\right)$ occurs in nature as a mineral and can be used for dielectric ceramics.

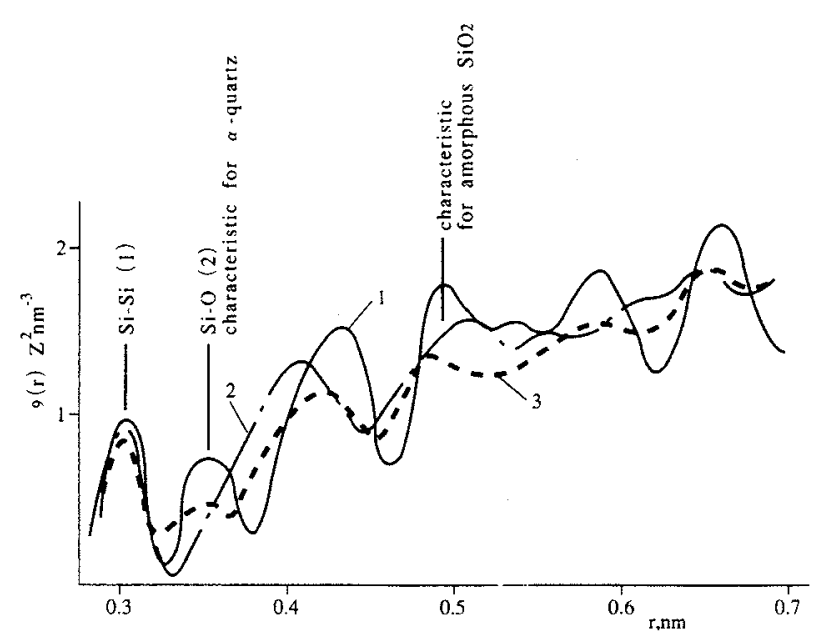

Fig. 2 Radial distribution function. (RDF). $1=\alpha$-quartz, $2=$ amorphous $\mathrm{SiO}_{2}, 3=\alpha$-quartz after $70 \mathrm{~h}$ of mechanical treatment, $r=$ distance of an arbitrary atom from the origin (8). 
There are indications that it may gain in significance in the fixation of radioactive waste ${ }^{29,30)}$. There are various technical methods for the preparation of titanite ${ }^{31,32)}$. According to $\mathrm{Mi}$ chailova et al. $^{33)}$, the synthesis temperature is lowest if quartz sand is used as the $\mathrm{SiO}_{2}$ component (Fig. 3,a). In the following it will be shown that in the production of titanite, quartz sand can be used and advantage may be taken of the reactivity-raising effect of its mechanical activation $^{34,35,36)}$.

As the second reaction component, calcium titanate (synthetic perowskit) was used. With the use of calcium titanate and quartz sand the reaction at temperatures up to $1280^{\circ} \mathrm{C}$ leads to an incomplete transformation (Fig. 3,b). Higher temperatures bring about a complete transformation, but cannot be used because of the occurrence of disturbing sinter effects causing a hardening of the product. On the other hand, the use of mechanically-activated quartz sand leads to a complete titanite transformation already at $1250^{\circ} \mathrm{C}$ (Fig. 3,c). In this case, a temperature decrease of $30^{\circ} \mathrm{C}$ is not significant in itself, but the fact that the reaction is shifted to a temperature region in which no sinter effects occur is of critical importance.

$$
\begin{aligned}
& \mathrm{a}-\mathrm{CaCO}_{3}+\mathrm{TiO}_{2}+\mathrm{SiO}_{2}(\text { quartz }) \frac{1250^{\circ} \mathrm{C}}{-\mathrm{CaTiSiO}_{5}+\mathrm{CO}_{2}} \\
& \text { (by Michailova) } \\
& \mathrm{b}-\mathrm{CaTiO}_{3}+\mathrm{SiO}_{2}(\text { quartz }) \stackrel{>1280^{\circ} \mathrm{C}}{-} \mathrm{CaTiSiO}_{5} \\
& \mathrm{c}-\mathrm{CaTiO}_{3}+\mathrm{SiO}_{2} \text { (mechan. activated quartz) } \stackrel{\approx 1250^{\circ} \mathrm{C}}{\longrightarrow} \mathrm{CaTiSiO}_{5}
\end{aligned}
$$

Fig. 3 Reaction equations for the formation of $\mathrm{CaTiSiO}_{5}$ (36).

There are optimal conditions for the reaction with regard to the mechanically-generated disturbances. The specific surface area alone is not the decisive parameter (see Table 1). Table 1 contains the temperatures at which the transformation to titanite is complete. The solid reaction starts at $1050^{\circ} \mathrm{C}$ and is completed at $1250^{\circ} \mathrm{C}$, whereby the main quantity of $\mathrm{CaTiSiO}_{5}$ - about $90 \%$ - is already formed at $1180^{\circ} \mathrm{C}$. It was not possible by the transformation of quartz into a completely amorphous state or by the use of amorphous aerosil to further lower the reaction temperature of titanate under the given conditions.

In the formation of titanite from quartz, cris-
Table 1 Dependence of the temperature $T$ during a 100 percent transformation of titanate and quartz to titanite on the starting component.

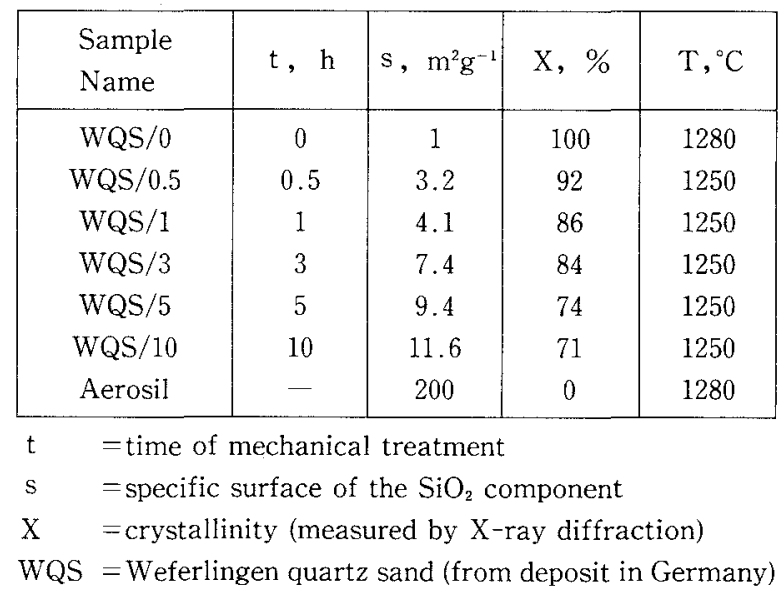

tobalite occurs as an intermediate product. The lower the temperature of the transformation of quartz into cristobalite, the lower the formation temperature of titanite. (The transformation temperature of mechanically-activated quartz is $>1200^{\circ} \mathrm{C}$, see section 2.1 .2 )

The crystallites of the initial products become covered by the reaction products (Fig. 4). In this figure, distinct growth regions with a layer-like structure are to be seen. The "layer" heights are of the order of some $10 \mathrm{~nm}$. Titanite has grown upwards on the original titanate crystals during the reaction. The diffusion of the ions involved takes place through the cover layer. $\mathrm{Ca}$ and $\mathrm{Ti}$ could be detected by element analysis.

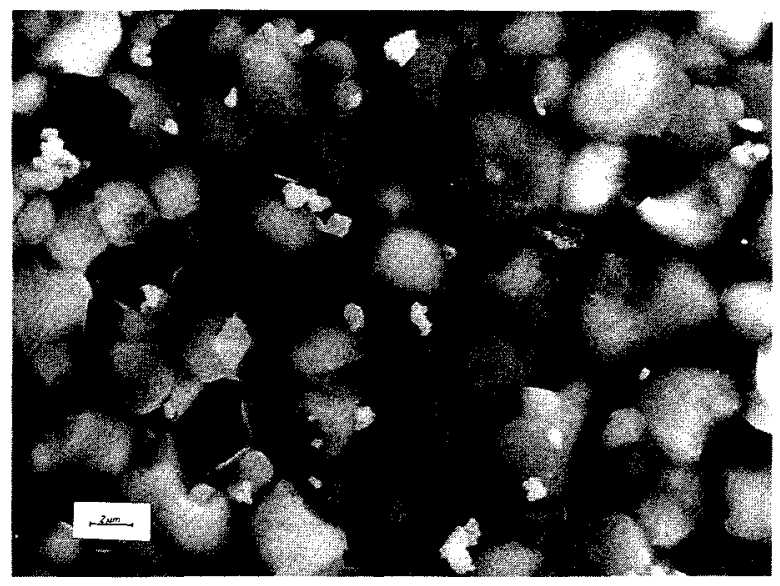

Fig. 4 Titanate formation on titanite crystals $\left(1200^{\circ} \mathrm{C}\right.$, ih halt) (36). 
On the basis of the results, the formation of titanite is assumed to occur via a one-sided diffusion of cations (Fig. 5). The $\mathrm{Ca}^{2+}$ and $\mathrm{Ti}^{4+}$ ions or the corresponding oxygen-ion complexes diffuse into the quartz lattice which is in a reactive state of transformation into cristobalite. This transformation is a reconstructive one in which $\mathrm{Si}-\mathrm{O}$ bonds have to be broken. The breakage of these $\mathrm{Si}-\mathrm{O}$ bonds is facilitated by the mechanically-induced bond breakages and the generated distortions and deformations of the $\mathrm{SiO}_{4}$-tetrahedrons with each other ${ }^{8}$.

This also explains the formation of titanite at lower temperatures when mechanically-activated quartz is used. It is of decisive importance that the quartz lattice is in a state of transformation. The $\mathrm{Si}^{4-}$ ions or complexes being formed diffuse along the grain boundaries of the titanite crystallites being generated to the surface of titanate and react with titanate. From the crystal-chemical point of view, a diffusion into the titanate-lattice is not likely.

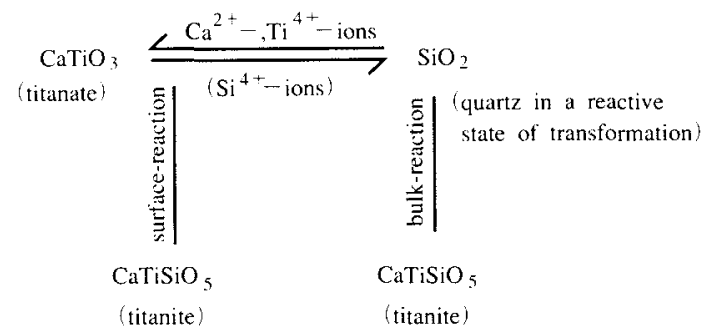

Fig. 5 Formation of titanite by one-sided diffusion of ions (36).

\subsubsection{Polymorphous Quartz Transformation}

Polymorphous intermediate transformations of $\mathrm{SiO}_{2}$, which may occur during or as a result of a complete transformation, are of great importance for the reaction of silicates because of reactivity, as shown in the case of the titanite formation. It is known from literature that mechanical deformation processes may influence the velocity, as well as the mechanism of the modification transformations ${ }^{37,38)}$.

Without the influence of mechanical treatment, the polymorphous transformations of the most important $\mathrm{SiO}_{2}$-modifications proceed according to Fenner ${ }^{39)}$, as shown in Fig. 6. Under the influence of mechanical treatment, the effect (degree) of the $\alpha-\beta$ - transformation decreases ${ }^{49}$. Strongly disturbed quart $z$ is not transformable into the high-temperature form.
The non-appearance of the transformation effect may be accounted for by a strong disturbance of the lattice. The $\alpha-\beta$-transformation is based on insignificant displacements of the atom positions, a deformation of the lattice. In the case of the mechanically-activated quartz, however, a growing part of the 6-ring arrangement has already been destroyed. As a result of the mechanical activation the temperature of the quartz-cristobalite transformation is strongly reduced (Fig. 6,b). The quartz-cristobalite transformation is, as already mentioned, a reconstructive one in which the structures have to be completely reorganized and breakage of the $\mathrm{Si}-\mathrm{O}$ bonds is necessary.

$$
\begin{aligned}
& \text { (a) } \alpha \text {-quartz } \stackrel{573^{\circ} \mathrm{C}}{\longrightarrow}, 3 \text {-quartz } \stackrel{870^{\circ} \mathrm{C}}{\longrightarrow}, 3 \text {-tridymite } \stackrel{1470^{\circ} \mathrm{C}}{\longrightarrow}, 3 \text {-cristobalite } \\
& \text { (b) } \alpha \text {-quartz } \frac{\geq 1200^{\circ} \mathrm{C}}{\text { (mechan. activated) }}, 3 \text {-cristobalite }
\end{aligned}
$$

Fig. 6 Polymorphous transformation of quartz. a) by Fenner $(39)$, b) induced by mechanical treatment (40).

The breakage of $\mathrm{Si}-\mathrm{O}$ bonds, and the relative distortion of the $\mathrm{SiO}_{4}$ tetrahedrons facilitate the necessary disintegration of the structure, and play an essential role in the accelerated transformation at a lower temperature. The velocity constants $k_{1}$ and $k_{2}$ were determined from the time-dependence of the quartz-cristobalite transformation taking as a basis the mechanism derived by $\mathrm{Mitra}^{41}$. On the basis of its temperature-dependence, the activation energy $A_{E}$ of both partial steps may be estimated to have the values shown in Fig. 7. The activation energy of both partial steps is reduced by a factor of two by mechanical activation. The activation energy of the transformation leading to cristobalite is slightly higher than that of the transformation quart $z \rightarrow$ transition phase. This fact can be explained by nucleation processes. The mechanically-induced elementary defects have no influence on the transformation quartz $\rightarrow$ transition phase, i.e. on the structure of the quartz lattice, but on the new formation of cristobalite, because the activation energies for both processes are considerably lowered. Accordingly, the produced defects must still be effective in the supposed transition phase, presumably in sub-microscopic small lattice regions no longer showing any diffraction ${ }^{41}$. 
a - quart $z \frac{k_{1}}{i_{1}}$ transition phase $\frac{k_{2}}{2}, 3-$ cristobalite

Activation energies $A_{E}, \mathrm{~kJ} \mathrm{~mol}^{-1}$
$\begin{aligned} & \text { quartz. } \\ & \text { (before mech.treatment) }\end{aligned}$
$\begin{aligned} & \text { quartz } \\ & \text { (mech.treated, land } 3 \mathrm{~h}, \text { resp.) }\end{aligned}$

Fig. 7 Activation energies $A_{E}$ for mechanically-induced quartz-cristobalite transformation $\left(\mathrm{k}_{1}, \mathrm{k}_{2}\right.$ rate constants (40)).

\subsubsection{Zeolite Formation}

Zeolites are generally produced from solution containing alkaline silicates and aluminates via hydrothermal synthesis by precipitation or by a hydrogel procedure. The formation of zeolite by the reaction of quartz with aluminium oxide $^{42)}$ is also possible. In this case, the ratedetermining step is the dissolution of quartz. The elementary step of the dissolution is influenced by lattice defects ${ }^{43}$, e.g. bond breakings, distortions and deformations normally associated with mechanical activation ${ }^{44)}$.

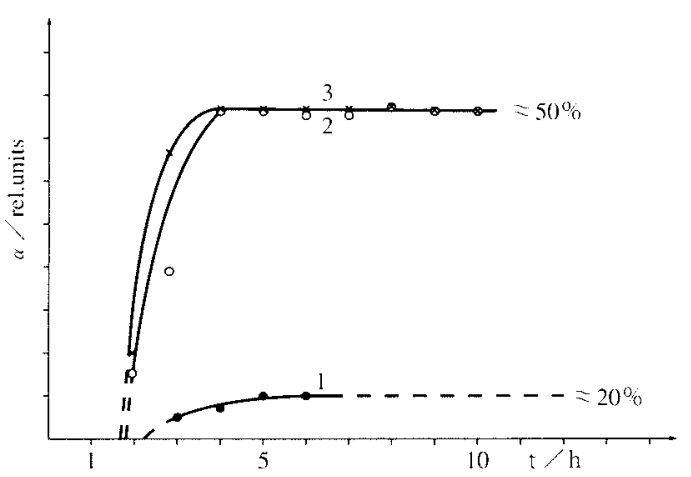

Fig. 8 Dependence of sodium A zeolite formation from mechanically-activated quart $z$ and $\alpha-\mathrm{Al}_{2} \mathrm{O}_{3}$ on the reaction time t. Experimental conditions: $2 \mathrm{~m} \mathrm{NaOH}$, $\mathrm{T}=90^{\circ} \mathrm{C}$, time of the mechanical mixing of quartz and $\alpha-\mathrm{Al}_{2} \mathrm{O}_{3}: 3 \mathrm{~h}$ (45) (see Table 2). Mol ratio quartz: $\gamma-\mathrm{Al}_{2} \mathrm{O}_{3}=2: 1$.

Fig. 8 and Table 2 show the zeolite formation ( $\mathrm{NaA}$-zeolite) from mechanically-activated quartz and $\gamma-\mathrm{Al}_{2} \mathrm{O}_{3}$ as a function of reaction time ${ }^{45)}$. The transformation to zeolite first increases with mechanical activation but then remains constant. Essentially, the transformation as a whole increases with decreasing crystallinity of quartz. $\mathrm{X}$-ray investigations reveal that only the disturbed, partially crystal line part of the quartz dissolves and reacts with $\gamma-\mathrm{Al}_{2} \mathrm{O}_{3}$ during the formation of $\mathrm{NaA}$-zeolite. Under the chosen circumstances, the formation of $\mathrm{NaA}$-zeolite is only possible to the extent that partially crystalline quartz is available, i.e. quartz which still contains the basic elements of a crystalline structure. With the use of amorphous $\mathrm{SiO}_{2}$, e.g. aerosil, the species $\mathrm{B}$ is formed.

Table 2 Characterization of the samples for the zeolite formation.

\begin{tabular}{|c|c|c|c|c|} 
& $\mathrm{X}, \%$ & $\mathrm{~s}_{1}, \mathrm{~m}^{2} \mathrm{~g}^{-1}$ & $\mathrm{~s}_{2}, \mathrm{~m}^{2} \mathrm{~g}^{-1}$ & $\alpha, \%$ \\
\hline sample 1 & 100 & $<1$ & 11.8 & ca. 20 \\
sample 2 & 50 & 10 & 25 & ca. 50 \\
sample 3 & 45 & 14 & 17 & ca. 50 \\
\hline
\end{tabular}

$\mathrm{X}=$ crystallinity (measured by $\mathrm{X}$-ray diffraction) of quartz

$\mathrm{s}_{1} \quad$ = specific surface of quartz

$\mathrm{s}_{2}=$ specific surface of quartz $/ \gamma-\mathrm{Al}_{2} \mathrm{O}_{3}-$ mixture

$\alpha=$ turnover to zeolite

\subsubsection{Mechanically-Induced Adsorption of Quartz}

An essential partial step in the reaction of a solid with the surroundings, e.g. a gas atmosphere, is its ability to $a b-$ or adsorb gas. It appears that this process is also influenced by mechanical activation forces, and the structural changes of the solid associated with such activation $^{46)}$.

Generally, it can be stated that the amount of gas $\mathrm{ab}-$ and adsorbed increases with an increasing degree of the disturbance of quartz, but in a different way for the individual gases, as can be seen from Fig. 9. Highest is the adsorption of $\mathrm{H}_{2}$, then follows that of $\mathrm{CO}_{2}$ and $\mathrm{O}_{2}$. Ar as a noble gas is not adsorbed at room temperature.

Mechanically-induced absorption primarily occurs during the action of energy. If the gas is added after the mechanical activation, there is only an adsorption at the surface and practically no diffusion of the gas molecules into the solid, i.e. the absorption is negligible.

It is assumed that during the treatment the pores are greater and that the whole lattice is loosened to a greater extent than the subsequent integral measurements reveal. 'The gases are absorbed both chemically and physically. The chemisorption occurs primarily on the basis of the $\mathrm{Si}^{-} \mathrm{O}$ bond breakages produced, which are determined by chemical gas 
Thus it must be concluded that not only the structural properties of solids, but also the chemical properties of both solid and gas play important roles with regard to $a b-$ and adsorption of gases.

\subsection{Reactivity of Mechanically-Treated Hydrargillite}

Aluminium oxides are one of the main compo-

Fig. 9 Dependence of the number of adsorbed molecules $\mathrm{N}$ on the amorphous part $\mathrm{A}$ in mechanically-treated quartz (46).

interactions ${ }^{8,46)}$. But far more molecules are taken up than correspond to the number of the measured centres ${ }^{46)}$, Table 3 . The physical adsorption is mostly influenced by the following structural factors (Table 3).

Quartz, because of the small size of the micropores present, does not usually contain much gas, and only traces of $\mathrm{H}_{2}$ can normally be detected. The gas kinetic diameter of $\mathrm{H}_{2}$ is approximately comparable with the diameter of the quartz pores. That is why $\mathrm{H}_{2}$ is also slightly absorbed by untreated quartz. On the other hand, the gas kinetic diameters of $\mathrm{H}_{2}, \mathrm{O}_{2}$ and $\mathrm{Ar}$ are all of the same order of magnitude as the pores in mechanically-activated material, but Ar is still not absorbed. Presuming that only the size of the pores has a decisive influence on the absorption, there should be no $\mathrm{CO}_{2}$ absorption. While the structural changes and the resulting locally generated energy states at the surface and in the disturbed quartz layer are of decisive importance, they do not completely account for the differences in the amounts of the individual gases absorbed. nents for the production of catalytic materials and adsorbents. The starting material for the technical production of surface-rich active aluminium oxides is hydrargillite. Aluminium oxides are produced via hydrargillite by a process of dissolving and precipitation. The shorttime heating of mechanically-pretreated hydrargillite is another possibility to obtain active aluminium oxides free of $\mathrm{Na}^{+}$.

The mechanical activation of hydrargillite has been the subject of several scientific investigations recently ${ }^{4-49}$, and has in the last few years gained in significance in connection with a short-time heating ${ }^{50-56)}$.

The basic concept of this alternative procedure consists in the transformation of hydrargillite by short-time heating into a nearly X-ray amorphous aluminium oxide, being well washable regarding $\mathrm{Na}^{+}$ions. Synthetic hydrargillite always contains $\mathrm{Na}^{+}$ions as contamination caused during preparation, which adversely affect the catalytic properties of aluminum oxides, prepared from $\mathrm{Al}(\mathrm{OH})_{3}$. Their removal is therefore necessary. The $\mathrm{X}$-ray amorphous $\mathrm{Al}_{2} \mathrm{O}_{3}$ is transformed in the same washing process to pseudo-boehmite ( $\mathrm{AlOOH}$ ) by hydration. Hydrargillite is pretreated by a mechanical treatment for rapid disintegration.

Table 3 Mechanically-induced adsorption on quartz (period of time of mechanical treatment : 4h).

\begin{tabular}{|c|c|c|c|c|c|c|c|}
\hline \multicolumn{2}{|c|}{ GA } & $\mathrm{s}, \mathrm{m}^{2} \mathrm{~g}^{-1}$ & $A, \%$ & N. $10^{-20}, \mathrm{~g}^{-1}$ & Z. $10^{-18}, \mathrm{~g}^{-1}$ & $\mathrm{~N} / \mathrm{Z}$ & $\delta, \mathrm{nm}$ \\
\hline \multicolumn{2}{|c|}{$\mathrm{Ar}$} & 14 & 42 & $<0.1$ & 5.9 & - & 0.37 \\
\hline \multicolumn{2}{|c|}{$\mathrm{H}_{2}$} & 10 & 48 & 11.3 & 0.9 & $1.10^{2}$ & 0.28 \\
\hline \multicolumn{2}{|c|}{$\mathrm{O}_{2}$} & 14 & 44 & 0.24 & 14.0 & 2 & 0.36 \\
\hline \multicolumn{2}{|c|}{$\mathrm{CO}_{2}$} & 16 & 64 & 2.6 & 0.9 & $3.10^{2}$ & 0.46 \\
\hline \multicolumn{8}{|c|}{ GA = Gas atmosphere } \\
\hline s & \multicolumn{7}{|c|}{$=$ Specific surface of quartz } \\
\hline A & \multicolumn{7}{|c|}{$=$ "Amorphous" content } \\
\hline \multicolumn{8}{|c|}{$=$ Number of adsorbed gas molecules } \\
\hline$Z$ & \multicolumn{7}{|c|}{$=$ Number of radicals } \\
\hline$\delta$ & \multicolumn{7}{|c|}{$=$ Diameter of the gas-molecule } \\
\hline
\end{tabular}


Table 4 Dependence of $\mathrm{Na}^{+}$-elimination of $\mathrm{X}$-ray amorphous $\mathrm{Al}_{2} \mathrm{O}_{3}$ on mechanical and thermal ${ }^{\mathrm{x}}$ activation.

\begin{tabular}{|c|c|c|c|c|c|c|}
\hline \multicolumn{5}{|c|}{ Hydrargillite } & \multicolumn{2}{|c|}{$\mathrm{X}$-ray amorphous $\mathrm{AL}_{2} \mathrm{O}_{3}$} \\
\hline & Sample & $\mathrm{t}, \min$ & $\begin{array}{l}\text { do, rel. } \\
\text { units } \\
( \pm 0.1)\end{array}$ & $\begin{array}{c}\mathrm{s} \\
\mathrm{m}^{2} / \mathrm{g} \\
( \pm 5 \%)\end{array}$ & $\begin{array}{c}\mathrm{s} \\
\mathrm{m}^{2} / \mathrm{g} \\
( \pm 5 \%)\end{array}$ & $\begin{array}{c}{ }^{\mathrm{c}} \mathrm{Na}_{2} \mathrm{O}, \text { mar\% } \\
\pm 0.005\end{array}$ \\
\hline & 1 & 5 & 0.7 & 2.9 & 206 & 0.019 \\
\hline & 2 & 30 & 0.6 & 10.5 & 169 & 0.017 \\
\hline & 3 & 60 & 0.4 & 16.0 & 23 & 0.016 \\
\hline & 4 & 900 & 0.1 & 27.0 & 11 & 0.011 \\
\hline $\mathrm{x}$ & \multicolumn{6}{|c|}{$=$ Conditions of thermal activation : $0.2 \mathrm{~s}, 500^{\circ} \mathrm{C}$} \\
\hline $\mathrm{t}$ & \multicolumn{6}{|c|}{$=$ Mechanical pretreatment } \\
\hline do & \multicolumn{6}{|c|}{$=$ Degree of order, measured by $\mathrm{X}$-ray diffraction } \\
\hline $\mathrm{s}$ & \multicolumn{6}{|c|}{$=$ Specific surface } \\
\hline${ }^{\mathrm{c}} \mathrm{Na}_{2} \mathrm{O}$ & \multicolumn{6}{|c|}{$=\mathrm{Na}_{2} \mathrm{O}$ content of the solid } \\
\hline
\end{tabular}

The mechanical treatment of hydrargillite influences the thermal disintegration of hydrargillite ${ }^{56,57}$. Of special interest is the fact that after a mechanical and thermal short-time heating $\left(550^{\circ} \mathrm{C}\right.$, residence time $\left.<10 \mathrm{~s}^{55,56)}\right)$ an aluminium oxide is formed, which is characterized by a very high reactivity. Table 4 shows the $\mathrm{Na}^{+}$-elimination from $\mathrm{X}$-ray amorphous aluminium oxides as a function of the produced degree of order do (do measured in relative units from the $\mathrm{X}$-ray determined intensity of the (100) reflex) and the specific surface after the short-time heating. The $\mathrm{Na}^{+}$-elimination increases whereas the specific surface decreases.

Parallel to the $\mathrm{Na}^{+}$-elimination, a rehydration takes place. The reaction of aluminium oxides with water at $90^{\circ} \mathrm{C}$ yields pseudo- boehmite, which differs from crystalline boehmite with regard to the Bragg-reflexes (profile and position) and the IR spectra ${ }^{56)}$. The pseudoboehmite content increases with the reaction time (Fig. 10) and reaches a final value after about $30 \mathrm{~min}$. From this figure it also follows that the initial velocity of the pseudo-boehmite formation depends on the mechanical pretreatment.

The mechanical treatment of hydrargillite prior to the short-time heating increases the pseudo-boehmite yield. Fig. 11 displays the dependence of the pseudo-boehmite-transformation on the duration of the mechanical pretreatment of hydrargillite and the degree of order do of the pretreated hydrargillite. The formation of pseudo-boehmite is also not dependent on the specific surface of aluminium oxide since it decreases in the same measure as the pseudo-boehmite content increases (Fig. 11

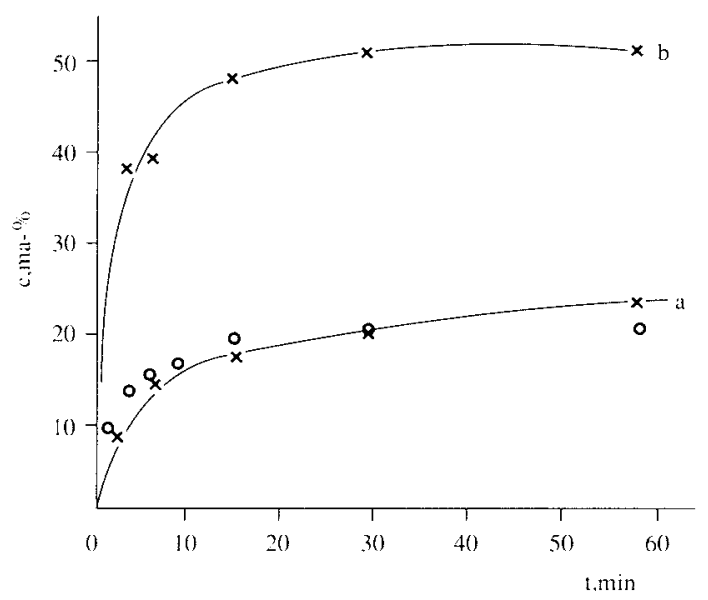

Fig. 10 Dependence of hydration of $\mathrm{X}$-ray amorphous $\mathrm{Al}_{2} \mathrm{O}_{3}$ on the time $t$ (different mechanically-treated hydrargillite, vibration mill), $\mathrm{T}=90^{\circ} \mathrm{C}$ do $=$ degree of order $\mathrm{a}$ : do $=0.73 \mathrm{~b}$ : do $=0.52 \mathrm{c}=$ content of pseudo -boehmite (56).

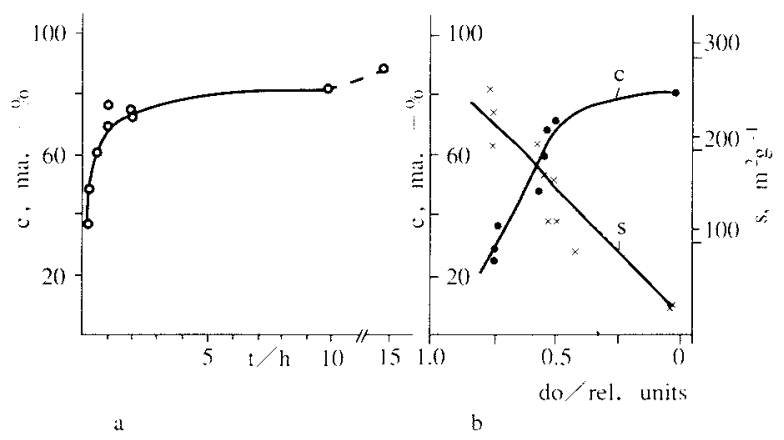

Fig. 11 Dependence of the content of pseudo-boehmite $c$ (after short-time heating and hydration) on the duration of mechanical treatment $t$ (a) and on the degree of order do (b, c) of hydrargillite, and the dependence of the specific surface s (after mechanical and thermal activation) on the degree of order do $(b, s)$. 
and Table 4). The reaction of aluminium oxide with $\mathrm{H}_{2} \mathrm{O}$ also yields bayerite. The bayerite formation depends only slightly, however, on the mechanical pretreatment (the bayerite content rises with increased mechanical pretreatment from $0-5 \%$ ). The bayerite formation is essentially determined by the temperature and reaction time. The aluminium oxides present are nearly $\mathrm{X}$-ray amorphous and contain some $\chi-\mathrm{Al}_{2} \mathrm{O}_{3}$ (Table 5). The short-range order was determined from the radial distribution function of the electron density by $\mathrm{X}$-ray wideangle investigations, Fig. 12 ${ }^{58}$. The position of the lst peak at $0.188 \mathrm{~nm}$ corresponds to the $\mathrm{Al}^{-}$ $\mathrm{O}$ distance and is independent of the method of preparation. Also the position of the other peaks remain unchanged. However, beginning from the 2nd peak $(r>0.3 \mathrm{~nm})$, there are differences in the intensities due to distortions of the coordination polyhedrons.

Table 5 Characterization of the samples after mechanical and thermal activation.

\begin{tabular}{|c|c|c|c|}
\hline & sample name & $\mathrm{AL}_{2} \mathrm{O}_{3}-$ phase & $c, \%^{x}$ \\
\hline & 1 & $X+r \cdot a^{x x}$ & 40 \\
\hline & 2 & $\mathrm{X}+\mathrm{r} . \mathrm{a}$ & 60 \\
\hline & 3 & r. $a+X$ & 73 \\
\hline & 4 & r. $a+X$ & 89 \\
\hline $\mathrm{x} \times$ & \multicolumn{3}{|c|}{$=\mathrm{X}-$ ray amorphous } \\
\hline $\mathrm{x}$ & \multicolumn{3}{|c|}{$\begin{aligned}= & \mathrm{IR}-\text { spectroscopy, Dr. Geissler, } \\
& \text { Zentrum Berlin }\end{aligned}$} \\
\hline
\end{tabular}

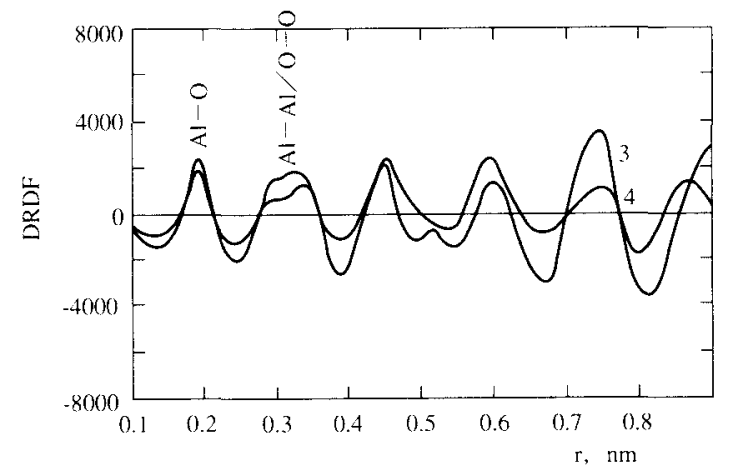

Fig. 12 Difference radial distribution function (DRDF). $\mathrm{DRDF}=4 \pi \mathrm{r}^{2}\left(\delta(\mathrm{r})-\delta_{0}\right) \mathrm{r}=$ distance of an arbitrary atom from the origin (sample names see Tables 4,5 ) (58).
The greater the distortion of the polyhedrons, the higher is the degree of rehydration of aluminium oxides. The energy stored as a result of mechanically-caused distortions facilitates the formation of boehmite from aluminum oxide and water $\left(\mathrm{Al}_{2} \mathrm{O}_{3}+\mathrm{H}_{2} \mathrm{O} \rightarrow \mathrm{Al}(\mathrm{OOH})\right)$. The reason for the distortion of the coordination poly. hedrons is the mechanical pretreatment in connection with the subsequent short-time heating. The distortion increases with the length of time of the mechanical pretreatment ${ }^{58}$.

\section{Conclusions}

Summarizing, it can be stated that under the influence of mechanical energy, solids undergo structural changes and structural defects which lead to an energy storage, which may result in an enhancement of chemical reactivity. Correlations exist between the mechanically-induced structural defects and the mechanism of the reactions.

The particle disintegration accomplished by mechanical activation and the resulting increase in surface area may be of importance for an increase of reactivity, but a number of publications have shown that the measured effect of the reactivity enhancement cannot be explained merely by these phenomena.

One of the cited examples even demonstrates that the reactivity enhancement may be inversely proportional to the increase in surface.

Table 6 contains a list of the investigated reactions as a function of structural defects. Apart from the structural properties of the solids, however, both the chemical properties of solids and those of the surroundings are of importance. 
Table 6 The dependance of the reactivity of solids on their mechanically changed structure.

\begin{tabular}{|c|c|}
\hline Reaction & Correlation with the changed structure \\
\hline $\begin{array}{ll}\text { Solid-solid } \\
-\quad \alpha-\beta \text {-quartz transformation } \quad[40] \\
\text { quartz-cristobalite } \\
\text { transformation }\lceil 40] \\
\text { titanite formation } \\
\quad\left(\text { mechanically-treated quartz }+\mathrm{CaTiO}_{3}\right)\end{array}$ & $\begin{array}{l}\text { partially crystalline state }\{8,60\} \\
\text { partially crystalline state, with broken } \mathrm{Si}-\mathrm{O} \text { bonds and } \\
\text { distortions of the } \mathrm{SiO}_{4} \text {-tetrahedrons } \\
\text { quartz lattice being in a state transformation into cris- } \\
\text { tobalite in connection with partially crystalline state }\end{array}$ \\
\hline $\begin{array}{l}\frac{\text { Solid-liquid }}{-} \\
\text { dissolution of quartz } \\
-\quad \text { Zeolithe formation } \\
\left.\text { (mechanically - treated quartz }+\gamma-\mathrm{Al}_{2} \mathrm{O}_{3}+\mathrm{NaOH}\right) \\
{[45]} \\
\mathrm{CSH} \text {-formation (mechanically-treated } \\
\left.\text { quartz }+\mathrm{Ca}(\mathrm{OH})_{2}+\mathrm{H}_{2} \mathrm{O}\right)[59] \\
\text { rehydration of } \mathrm{Al}_{2} \mathrm{O}_{3}\left(\mathrm{Al}_{2} \mathrm{O}_{3}+\mathrm{H}_{2} \mathrm{O} \cdots>\mathrm{AlOOH}\right) \\
\quad[56,58]\end{array}$ & $\begin{array}{l}\text { partially crystalline state, with broken } \mathrm{Si}-\mathrm{O} \text { bonds and } \\
\text { distortions of the } \mathrm{SiO}_{4} \text {-tetrahedrons } \\
\qquad-n- \\
\text { distortions of the } \mathrm{Al}_{2} \mathrm{O}_{3} \text {-octrahedrons }\end{array}$ \\
\hline$\frac{\text { Solid-gas }}{\text { mechanically-induced adsorption of quartz }}$ & $\begin{array}{l}\text { partially cristalline state, broken } \mathrm{Si}-\mathrm{O} \text { bonds, radicals and } \\
\text { chemical defects }\end{array}$ \\
\hline
\end{tabular}

\section{References}

1) Ostwald, W.: Handbuch der allg. Chemie I, Leipzig, 191.9, 70

2) Heinicke, G.; Hennig, H.-P.; Linke, E.; Steinike, U.; Thiessen, K.P.: Tribochemistry, Akademie-Verlag Berlin 1984, Carl Hanser-Verlag, München 1984. Verlag Mir, Moskau 1987 (in Russian)

3) Tamman, G.: Z. Elektrochem., 35 (1929), 21

4) Fink, M.: Trans. Am. Soc. f. Steel Treating, 18 (1930), 1026

5 ) Fink, M.; Hoffmann, U.: Z. anorg. allg. Chemie, 210 (1933), 100

6) Bowden, F.F.; Tabor, D.: The friction and lubrication of solids, Oxford 1958.

7) Thiessen, P.A.: Abhandlungen der Dt. Akademie der Wissenschaften zu Berlin, Klasse $\mathrm{f}$. Chemie, Geologie und Biologie, 5 (1966), 15

8 ) Steinike, U.; Kretzschmar, U.; Ebert, I.; Hennig, H.-P.; Barsova, L.I; Jurik, T.K.: Reactivity of Solids, 4 (1987), 1

9 ) Heegn, H.: Veränderung der Festkörpereigenschaften bei mechanischer Aktivierung und Feinzerkleinerung, Dissertation B, Akademie der Wissenschaften der DDR,

\section{Berlin (1986)}

10) Soc. of Pow. Tech., Japan: Proceedings of the Second Japan-Soviet Symp. on Mechanochemistry, 22-24 March 1988, Tokyo

11) 5th Symp.: Theoretical and Technological Aspects of Comminution and Mech. Activation of Minerals: Tataraman 1988.

12) Gock, E.; Asiam,E.: in (11), 60.

13) Schulz, G.; Dietzel, W.: Abfall-WirtschaftsSymp., 4-7 Dec. 1990, Berlin. I. Integrierte Abfallwirtschaftskonzepte, 3, 265 (1990). EFVerlag f. Energie und Umwelttechnik $\mathrm{GmbH}$.

14) Schultz, L.; Hellster, E.; Zorn,G.: Z. phys. Chem., NF 157 (1988), 203

15) Ikeya, T.; Senna, M.: J. Non-Crystalline Solids, 113 (1989), 51

16) Pavlyukhin, Yu.T.; Medikov, Ya.Yu.; Boldyrev, V.V.: J. of Solid State Chemistry, 53 (1984), 155

17) Pavlyukhin, Yu.T.; Medikov, Ya.Yu.; Boldyrev, V.V.: Mat. Res. Bull. 18 (1983), 1317

18) Imamura, K.; Senna, M.: Mat. Res., Bull. 19 (1984), 59

19) Balaz, P.; Huhn, H.-J.; Tkacova, K.; Heegn,H.: Erzmetall, 41 (1988), 6

20) Tkacova, K.; Balaz, P.; Korneva, T.A.: J. 
Therm. Anal., 34 (1988), 1031

21) Lin, I.J; Nadiv, S.; Groguian, D.J.M.: Minerals Sci. Engng., 7 (1975), 313

22) Tkacova, K.; Boldyrev, V.V.; Lyakhov, N.: Proc. Indian natn. Sa. Acad., 55A (1989), 778

23) Tkacova, K.; Balaz, P.; Bastl, Z.: Thermochimica Acta, 170 (1990), 277

24) Fubini, B.; Giamello, E.; Pugliese, L.; Volante, M.: Solid State Ionics, 32/33 (1989), 334

25) Giamello, E.; Fubini, B.; Volante, M.; Costa, D.: Colloids and Surface, 45 (1990), 155

26) Paudert, R. et al.: DD 222009.

27) Sigrist, K.; Fichtner,H.: Phys. Status Solidi, 95 (1985), 473

28) Thiessen, P.A.; Heinicke, G.; Schober, E.: Z. anorg. allg. Chem., 377 (1970), 28

29) Stäuble, J.; Bayer, G.: Schweiz. Mineral. Petr. Mit., 61 (1981), 361

30) White, T.J.; Segall, R.L.; Turner, P.S.: Angew. Chem., 97 (1985), 369

31) King, E.G.: Amer. Chem. Soc., 76 (1954), 4320

32) Völtzke, P.; Abicht, H.-P.; Müller, Th.; Richter, J.: Silikattechnik, 41 (1990), 306

33) Michailova, N.A.; Vinnikova, N.S.: Anorg. Werkstoffe, 15 (1979), 114

34) Köhler, Th.; Plötner, W.; Steinike, U.; Uecker, D.-Chr.; Schierhorn, E.: DD 263747

35) Plötner, W.; Köhler, Th.; Uecker, D.-Chr.; Steinike, U.: DD 254934

36) Steinike, U.; Uecker, D.-Chr.; Köhler, Th.; Plötner, W.; Schierhorn, E.; Jancke, K.; Hennig, H.-P.: Crystal. Res. Technol., 26 (1991)

37) Sigrist, K.; Heinicke, G.; Steinike, U.: Kristal und Technik, 8 (1973), 393

38) Senna, M.: KONA, 1 (1983), 48

39) Fenner, C.N.: Amer. J. Sci., 36 (1913), 331

40) Steinike, U.; Uecker, D.-Chr.; Sigrist, K.; Plötner, W.; Köhler, Th.: Crystal Res. Technol., 22 (1987), 1255

41) Mitra, S.: Trans. and J. Brit. Ceram. Soc., 76 (1977), 71

42) Cournager, R.A.; Kranich, W.L.; Sand, L. B.: J. of Phys. Chem., 79 (1975), 1578

43) Weyl, W.A.; Marboe, E.C.: Sprechsaal, 107 (1974), 1030
44) Steinike, U.; Hennig, H.-P.; Kretzschmar, U.; Richter-Mendau, J.: Crystal Res. Technol., 17 (1982), 1585

45) Wutzler, R.; Klevzov, D.; Steinike, U.; Hennig, H.-P.: Crystal Res. Technol., 26 (1991), 317

46) Steinike, U.; Hennig, H.-P.; Ebert, I.: Z. phys. Chem., Leipzig, 226 (1985), 302

47) Schrader, R.; Rump, H.; Sanner, G.: Z. anorg. allg. Chem., 350 (1967), 130

48) Pohl, K.; Haberecht, H.: DD 134365

49) Pohl, K.: Habilitationsschrift, TU Dresden, 1970

50) Vorobjev, Ju.K.; Schkrabina, R.A.; Moroz, T.D.; Fenelonov, V.B.; Zagrafskaja, R.V.; Kambarova, T.D.; Levickij, E.A.: Kinetika i kataliz, 22, 6 (1981), 1595

51) Zolotovskij, B.P.; Schkarin, A.V.; Krivoruchko, O.P.; Kriger, T.A.; Bujanov, R.A.: Izv. Sib. Otd. Akad. Nauk SSSR, Ser. Chim. Nauk, 17 (392) 6, 36 (1984)

52) Bollmann, U.; Engels, S.; Haupt, K.; Kobelke, J.; Becker, K.; Neubauer, H.-D.: Z. Chem., 25 (1985), 273

53) Zolotovskij, B.P.; Paramzin, S.N., Krivoruchko, O.P.; Bujanov, R.A.: Izv. Sib. Otd. Akad. Nauk SSSR, Ser. Chim. Nauk 17 (446) 6, 80 (1987)

54) Steinike, U.; Becker, K.; Bollmann, U.: Spectrum, 7 (1988), 24

55) Bollmann, U.; Becker, K.; Berger, H.-J.; Birke, P.; Engels, S.; Gruhn, G.; Jancke, K.; Kraak, P.; Lange, R.; Steinike, U.: Cryst. Res. Technol., 23 (1988), 1303

56) Steinike, U.; Geissler, H.; Hennig, H.-P.; Jancke, K.; Jedamzik, J.; Kretzschmar, U.; Bollmann, U.: Z. anorg. allg. Chemie, 590 (1990), 213

57) Neissendorfer, F.; Steinike, U.; Tolochko, B.P.; Sheromov, M.A.: Nucl. instr. and methods in Physics Res., A 261 (1987), 219

58) Kretzschmar, U.; Steinike, U.; Bollmann, U.; Lausch, H.: Cryst. Res. Technol., in press

59) Jedamzik, J.: Dissertation, Akademie der Wissenschaften der DDR, Berlin, 1982.

60) Steinike, U.; Ebert, I.; Hennig, H.-P.; Müller, B.: Cryst. Res. Technol., 14 (1979), 1469 